\title{
RARE METASTASIS OF BREAST CANCER TO MANDIBLE - A CASE REPORT
}

\author{
Franjo Cmrečak ${ }^{1}$, Zrinka Rendić-Miočevići ${ }^{1}$ Lidija Beketić-Orešković1 ${ }^{1,2}$ \\ ${ }^{1}$ Division of Radiotherapy and Internal Medicine Oncology, University Hospital for Tumors, \\ Sestre milosrdnice University Hospital Center, Zagreb, Croatia; \\ ${ }^{2}$ Department of Clinical Oncology, University of Zagreb School of Medicine, Zagreb, Croatia
}

\begin{abstract}
Summary
Breast cancer is the most common cancer in the female population. In Croatia, breast cancer makes up to $26 \%$ of all newly diagnosed cases of cancer in females. Breast cancer primarily metastasizes to bones, lungs, liver, brain and lymph nodes. We report a case of isolated metastasis of breast cancer to mandible in a 76-year-old female patient, who was diagnosed with cancer eleven years ago, which presented with difficult chewing, discrete pain, and continuing increase in tumor marker Ca15-3. Pathohistology of intraoral biopsy confirmed a breast cancer metastasis. The patient received with palliative radiotherapy and hormone therapy. Every oncological patient complaining about the disorders in the mandibular area must be subject to thorough examination and metastasis should be included in the differential diagnosis. Metastatic lesion in the mandible is a sign of disseminated disease, and the treatment is most often palliative.
\end{abstract}

KEY WORDS: breast cancer, metastasis, palliative radiotherapy

\section{Sažetak}

\section{RIJETKI SLUČAJ METASTAZE KARCINOMA DOJKE U MANDIBULI - PRIKAZ SLUČAJA}

Karcinom dojke je najčešća maligna bolest u ženskoj populaciji. U Hrvatskoj, karcinom dojke čini oko $26 \%$ svih novodijagnosticiranih karcinoma u žena. Karcinom dojke najčešće metastazira u kosti, pluća, jetru, mozak te limfne čvorove. U ovom radu prikazujemo slučaj izoliranog metastatskog karcinoma dojke u mandibuli kod 76 godišnje pacijentice, kojoj je karcinom dojke bio dignosticiran prije 11 godina. Pacijentica se prezentirala sa otežanim žvakanjem, diskretnom boli, te povišenjem tumorskog biljega Ca15-3. Metastaza je dokazana intraoralnom biopsijom. Pacijentica je liječena palijativnom radioterapijom i hormonskom terapijom. Svaki onkološki pacijent sa simptomima u području mandibule se mora detaljno obraditi, te se treba posumnjati i na mogući sekundarizam. Metastatski karcinom mandibule je znak diseminirane bolesti te je shodno tome liječenje najčešće palijativno.

KLJUČNE RIJEČI: karcinom dojke, metastaza, palijationa radioterapija

\section{INTRODUCTION}

Breast cancer is the most common cancer among women worldwide and the second leading cause of death from cancer in women after lung cancer. The most common sites of metastases are lymph nodes, bones, lungs, liver, and brain(1). According to the Croatian National Cancer Registry, there were 2748 newly diagnosed cases of breast cancer in Croatian in 2015 which is $26 \%$ of all newly diagnosed cases of cancer in woman in Croa- 


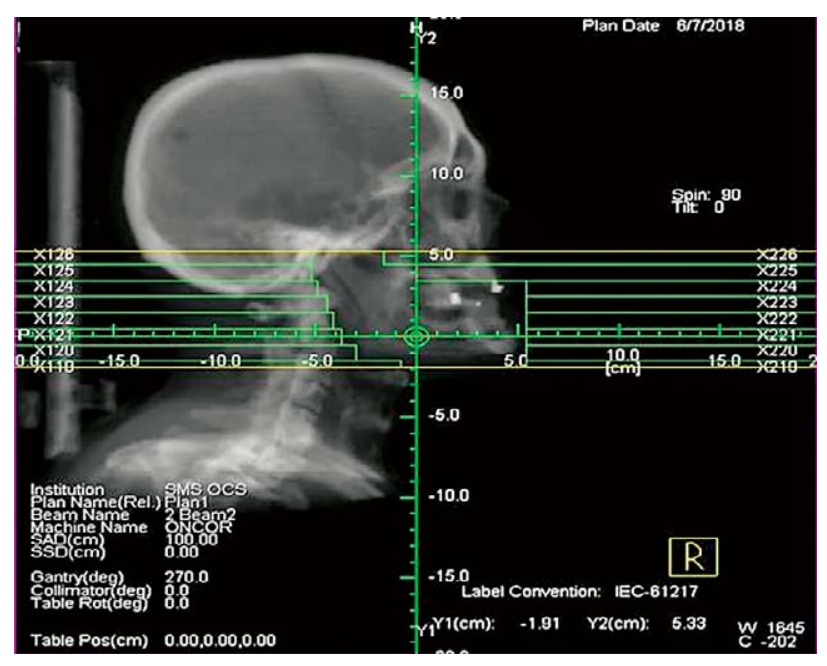

Figure 1. DRR (Digitally reconstructed radiography).

tia(2). The primary feature of cancer is its ability to invade tissues and metastasize. Metastasizing is a complex process in which tumor cell first must detach from the primary tumor, then invade blood or lymphatic vessels and survive in circulation. In microvasculature tumor cell extravasate through the vessel wall and invade the target organ. In order to successfully establish secondary tumor, cancer cells must be capable of proliferation and evasion of the immune system. Micrometastasis can grow up to 2-3 mm in size. For micrometastasis to grow beyond that size, a cancer cell must induce the formation of new blood cell for the adequate supply of oxygen and nutrients (3).

\section{PATIENT REPORT}

A 76-year-old female patient was diagnosed with left-sided breast cancer and treated with breast-conserving surgery and axillary dissection in 2007. Histopathology revealed invasive lobular carcinoma gradus II; tumor size was $3.8 \mathrm{~cm}$, estrogen receptor $100 \%$ positive, progesterone receptor $50 \%$ positive, Her- 2 negative and two of 16 axillary lymph nodes were cancerous. The patient received adjuvant chemotherapy: six cycles of adjuvant chemotherapy with $\mathrm{AC}$ regimen (Doxorubicin/Cyclophosphamide) between January and May 2008. Followed by the adjuvant radiation therapy in TD 50Gy in 25 fractions to the whole breast with the photon energy of $6 \mathrm{MV}$ and to the supraclavicular and infraclavicular region with a

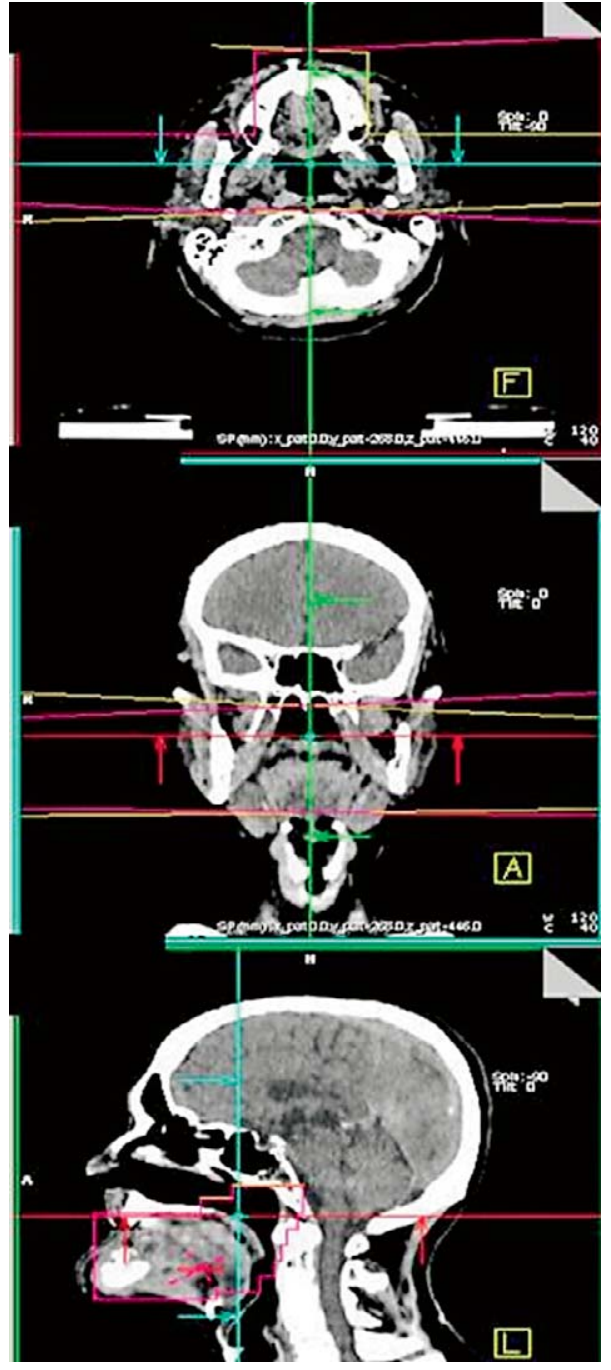

Figure 2. Photon fields in transversal, frontal and sagittal planes.

combination of photons energy $6 \mathrm{MV}$ and $15 \mathrm{MeV}$ electrons. Finally, the patient took endocrine therapy (anastrozole $1 \mathrm{mg}$ daily) for five years until 2013.

Regular annual follow up showed a continuing increase in tumor markers Ca15-3 in 2018. Afterward, the PET/CT showed pathologic accumulation of FDG (fluorodeoxyglucose) in the almost entire mandible (SUV max 12.5), with no other signs of active malignant disease. The patient had multiple teeth extraction a few months earlier, and we decided to ask for additional radiological. Computed tomography (CT) findings showed tumor mass in the corpus of the mandible with multiple 


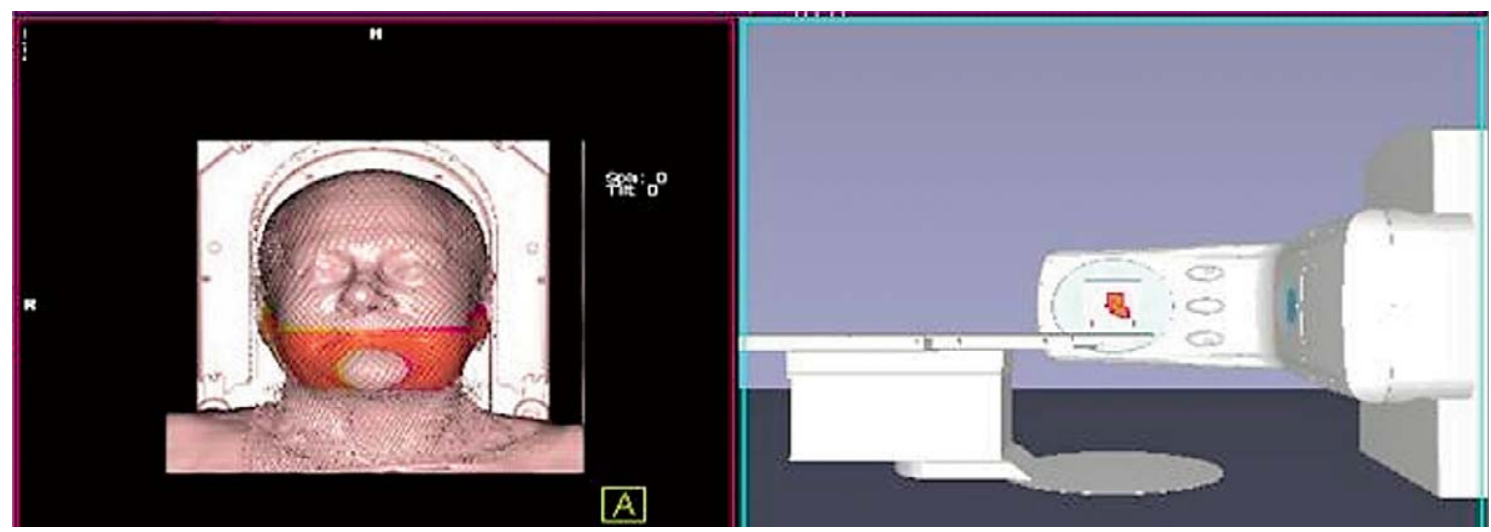

Figure 3. 3-D rendered CT image and position of the linear accelerator.

areas of the cortical bone defect. Her complaints were discrete pain, mild swelling in the mandibular area and painful chewing. We indicated an intraoral biopsy and histopathology confirmed metastasis of breast cancer. Tumor tissue was estrogen receptor $100 \%$ positive, progesterone receptor $80 \%$ positive, Her-2 negative, Ki-67 23\%.

In June 2018, the patient received palliative radiation therapy of the mandible through two laterolateral fields with a photon energy of 6MV. Total radiation dose was 39Gy in 13 fractions using VSIM technique (Figures 1-3). After radiation therapy, the patient started with tamoxifen hormone therapy. Two months after radiation and tamoxifen treatment, tumor marker CA 15-3 decreased from $38.5 \mathrm{U} / \mathrm{ml}$ to $28.2 \mathrm{U} / \mathrm{ml}$. Unfortunately, the patient had severe side effects of tamoxifen like hot flashes, fatigue, nausea and growing pain in the mandible. Given the stage and biology of the disease and side effects of tamoxifen, we discontinued the therapy. The patient started with chemotherapy regimen ribociclib plus exemestane and bisphosphonate treatment with ibandronic acid. After the first chemotherapy cycle, the patient felt better, with reduced pain in the mandible.

\section{DISCUSSION}

The metastatic tumors of the mandible are rare, especially the isolated ones. The metastatic malignant tumors of the oral cavity make only $1 \%$ of newly diagnosed malignant tumors of the oral cavity (4). Metastases are most often from breast cancer, prostate cancer, lung cancer, and colorectal cancer. Hirshberg analyzed 390 cases of meta- static tumors to the mandible. The most common site was breast $(21.8 \%)$, followed by lung, adrenal, kidney, colorectal, and prostate. There was a gender difference with regards to primary site: for women, it was breast tumor, followed by adrenal, colorectal, female genital organs, and thyroid gland tumor; for men, it was lung cancer, followed by the prostate, kidney and bone tumor (5).

Diagnosing a metastasis in the mandible can be challenging due to the lack of pathognomonic signs and symptoms. The common symptoms are the pain, progressing swelling, numbness of lower lip and chin, intraoral mass, loose or extruded teeth, cortical expansion, ulceration, halitosis, trismus and periodontal abscess (6). The differential diagnosis includes osteomyelitis, bone abscess, primary bone tumor, granuloma, multiple myeloma, lymphoma, acute leukemia, sarcoidosis, multiple sclerosis, sickle cell disease, Lyme disease, temporal arteritis (7). The radiological imaging analysis of the metastatic process of the mandible showed both osteolytic(86\%) and osteoblastic $(17 \%)$ lesions, and in approximately $5 \%$ of the cases, radiographs were negative (8). The lesion biopsy is mandatory especially if the patient has a history of malignant disease (9). Treatment of metastatic disease of the mandible is primary palliative and include radiotherapy, chemotherapy, hormone therapy and rarely surgery. Surgical treatment is only considered in the case of solitary metastasis. In this case, a multidisciplinary team opted for systemic hormone therapy and bisphosphonate therapy postpone the progression of disease (10). Eventually, the treatment should focus on pain relief and preservation of oral function. It 
is essential to prevent bleeding, infections, fracture, and cachexia (11).

\section{CONCLUSION}

We should evaluate every oncological patient's complaint about the disorders in a different part of the body than expected for a specific tumor type metastasis should. For solitary lesion of the mandible imaging methods such as CT, MRI, PET are recommended, followed by a biopsy. All inflammatory or reactive lesions in the lower jaw, in patient with malignant disease history are possible metastasis. The metastatic lesion of the mandible denotes disseminated disease, therefore the treatment is palliative.

\section{REFERENCES}

1. McGuire A, Brown JA, Malone C, McLaughlin R, Kerin MJ. Effects of age on the detection and management of breast cancer. Cancers (Basel). 2015;7(2): 908-29.

2. Croatian National Cancer Registry (The Croatian National Institute of Public Health)

3. Hanahan D, Weinberg RA. The hallmarks of cancer. Cell. 2000;100(1):57-70.

4. Dib LL, Soares AL, Sandoval RL, Nannmark U. Breast metastasis around dental implants: a case report. Clin Implant Dent Relat Res. 2007;9(2):112-5.
5. Hirshberg A, Leibovich P, Buchner A. Metastatic tumors to the jawbones: analysis of 390 cases. J Oral Pathol Med. 1994;23(8):337-41.

6. Poulias E, Melakopoulos I, Tosios K. Metastatic breast carcinoma in the mandible presenting as a periodontal abscess: a case report. J Med Case Rep. 2011;5:265

7. Schwartz ML, Baredes S, Mignogna FV. Metastatic disease to the mandible. Laryngoscope. 1988;98(3):270-3.

8. Hirshberg A, Shnaiderman-Shapiro A, Kaplan I, Berger R. Metastatic tumours to the oral cavity - pathogenesis and analysis of 673 cases. Oral Oncol. 2008;44(8): 743-52.

9. Varghese G, Singh SP, Sreela LS. A rare case of breast carcinoma metastasis to mandible and vertebrae. Natl J Maxillofac Surg. 2014;5(2):184-7.

10. Aerden T, Grisar K, Neven P, Hauben E, Politis C. Numb chin syndrome as a sign of mandibular metastasis: A case report. International Journal of Surgery Case Reports. 2017;31:68-71.

11. Stavropoulos MF, Ord RA. Lobular adenocarcinoma of breast metastatic to the mandibular condyle. Report of a case and review of the literature. Oral Surg Oral Med Oral Pathol. 1993;75(5):575-8.

Corresponding author: Lidija Beketić-Orešković, Department of Clinical Oncology, School of Medicine, University of Zagreb and Division of Radiotherapy and Medical Oncology, University Hospital for Tumors, Sestre milosrdnice University Hospital Center, Ilica 197, 10000 Zagreb, Croatia.e-mail: lidijabeketicoreskovic@gmail.com 